\title{
Using the accelerated Brazilian concrete prism test (ABCPT) to evaluate alkali aggregate reaction (AAR)
}

\section{Uso do método acelerado brasileiro de prismas de concreto (ABCPT) para avaliação da reação álcali-agregado (RAA)}

\author{
L. SANCHEZ \\ le.sanchez@uol.com.br \\ S. C. KUPERMAN b \\ selmo@desek.com.br \\ P. HELENE c \\ paulo.helene@poli.usp.br
}

\begin{abstract}
There are many test methods used in the laboratory to detect potential alkali-aggregate reactions (AAR). However, up to now, there is no consensus if they are reliable and efficient. This work presents the development of a new and accelerated concrete prism test called ABCPT (accelerate Brazilian concrete prism test) as an attempt to create a reliable and fast test that can analyze and classify the potential reactivity of aggregates in the laboratory. For this research, six aggregates from different lithotypes were used. The methods CPT, ACPT and ABCPT were carried out with all the aggregates and a comparative analysis among all tests was performed. ABCPT seems to have a great potential to analyze and classify aggregates in the laboratory, although it needs further testing with other lithotypes to be confirmed as feasible.
\end{abstract}

Keywords: alkali-aggregate reaction, test methods, concrete prism test (CPT), accelerated Brazilian concrete prism test (ABCPT).

\section{Resumo}

Existem muitos métodos de ensaio de laboratório utilizados na prevenção da reação álcali-agregado, entretanto, até o momento não existe consenso no que tange confiabilidade e eficiência destes. Este trabalho apresenta a tentativa de desenvolvimento de um novo método de ensaio acelerado denominado ABCPT (método acelerado brasileiro de prismas de concreto), com o intuito de que este possa, de maneira rápida e confiável, analisar e classificar agregados mediante a sua potencial reatividade em laboratório. Para o desenvolvimento desta pesquisa, foram utilizados seis litotipos diferentes de agregados. Os métodos CPT (método de prismas de concreto), ACPT (método acelerado de prismas de concreto) e ABCPT foram realizados com todos os agregados e após, uma análise comparativa foi realizada. Os resultados indicam que o ABCPT demonstra grande potencial para utilização na análise e classificação de agregados em obras correntes de engenharia. No entanto, para a sua real comprovação, torna-se muito importante a realização do ensaio com um maior número de amostras de diferentes litotipos.

Palavras-chave: reação álcali-agregado, métodos de ensaio, método de prismas de concreto (CPT), método acelerado brasileiro de prismas de concreto (ABCPT).

$P h D$ - PhD Engenharia e Consultoria Ltda. 


\section{Current scenery of test methods used to detect AAR potential}

It is already known that the best solution to face AAR in concrete structures is the prevention. Several researchers around the world have developed test methods to classify the potential reactivity of aggregates in the laboratory, before their use in the field.

After many years of study and development, most of the available test methods have not consistently produced reliable results and some distortions between laboratory and field behavior are often found [1].

In Brazil, the main test methods used are the petrographic analysis (according to NBR 15577-3), the accelerated mortar bar test (AMBT - according to NBR 15577-4), and the concrete prism test (CPT - according to NBR 15577-6).

\subsection{Petrographic analysis}

Petrographic analysis provides important information about the presence of potentially reactive minerals on the aggregates with the use of microscopic (optic and stereoscopic) analysis. This analysis can be carried out either in aggregates or concretes. Although very useful, the petrographic procedure is qualitative and by itself this analysis cannot detect the potential reactivity of an aggregate since many factors can influence in the deleterious chemical reaction [2].

\subsection{Accelerated mortar bar test (AMBT)}

The AMBT is somewhat similar to the NBRI test proposed by Oberholster and Davies (1985) [2]. This test was developed because the old mortar bar test (ASTM C 227 procedure) was too long and nowadays it is proven that it is not reliable enough.

There are many procedures that can be used for the test, among them the one proposed in the Brazilian standard NBR 15577-4 (Determination of the expansion of mortar bars by the accelerated test method). It consists, basically, in casting three mortar bars and soaking them into a $1 \mathrm{~N}-\mathrm{NaOH}$ solution at $80^{\circ} \mathrm{C}$ during 28 days. Before being immersed in the solution, the mortar bars are demolded after 24 hours and soaked into water at $80^{\circ} \mathrm{C}$ for another 24 hours. The accelerated test conducted according to the NBR 15577-4 classifies aggregates as potentially reactive or potentially innocuous in 30 days (i.e. 28 days in aggressive solution). The expansion limit used to distinguish a potentially innocuous or potentially reactive aggregate is $0.19 \%$ [3].

AMBT is not considered as reliable as it should by some researchers. They argue that this type of test is too severe for some aggregates and is not able to detect the potential reactivity of others [4]. Even though AMBT can classify aggregates in a very fast way, there are many factors that can affect the reactivity of the aggregate such as [3]:

- Alkali content of cement;

- Cement fineness;

- Size of aggregates;

- Water-cement ratio;

- Very aggressive environment (i.e. high temperature, $\mathrm{NaOH}$ solution);

- Proportion of materials used in the mortar.
Usually, AMBT is the first method used to classify aggregates rapidly. However, other methods should be used to provide a more reliable classification [5].

\subsection{Concrete Prism Test (CPT)}

The CPT procedure uses a cement content of $420 \mathrm{~kg} / \mathrm{m}^{3}$ and increases the alkali content to $1.25 \% \mathrm{Na}_{2} \mathrm{O}_{\text {eq }}$ by cement weight through the addition of $\mathrm{NaOH}$ in the mixing water. Concrete prisms are stored over water in sealed containers at $38^{\circ} \mathrm{C}$. An expansion limit of $0.04 \%$ at 1 year for the concrete prism is used to identify potentially reactive aggregates. The same limit is considered at 2 years as a threshold to qualify the mix for preventative measures [4]. According to Thomas et al. [4], there are no aggregates that pass the current test conditions and performance limits that have caused damaging alkali-silica or alkali-carbonate reaction in "real" concrete structures. However, it has been suggested that the test conditions may be too severe for some aggregates with good field performance, which could then be erroneously identified as being potentially reactive. On the other hand, it has been acknowledged that these same aggregates may cause deleterious reaction if they are placed in concretes with a high alkali content, such as the types of concrete commonly used nowadays in highway structures, which are often characterized by having relative high cement contents.

Even though CPT is recognized as a reliable test method, the test duration (1 year) practically disqualifies the method for wide use in real job conditions [6].

\section{Development of accelerated AAR test methods for concrete}

Given that previous results showed that the assessment of AAR in laboratory conditions is well done when concrete test methods are carried out, researchers started to study and develop new accelerated test procedures.

In the beginning of the 90's, Ranc and Debray proposed an accelerated test method that could, in less than 8 months, identify and classify the reactivity of aggregates to the alkali hydroxides from cement pore solution [7]. The test procedure developed was similar to the CPT but it is performed at $60^{\circ} \mathrm{C}$. A number of tests were carried out and this accelerated test was considered a powerful tool to detect the reactivity of aggregates with cement alkalis [4]. However, Fournier et al. alerted that in some cases leaching and the nature of the non-reactive sand used in a combination with the coarse aggregate under test can distort the results [7].

Trying to face the leaching problem, some researchers decided to soak concrete prisms into $\mathrm{NaOH}$ and $\mathrm{NaCl}$ solutions (with many different concentrations) as well as into water at $80^{\circ} \mathrm{C}$. After theses analysis, the authors [8] have concluded that:

- After 30 days at $80^{\circ} \mathrm{C}$, concrete prisms soaked into $\mathrm{NaOH}$ may already be analyzed and the aggregates classified according to their potential reactivity. Care needs to be taken to maintain the concentration of the solution, because variations could distort the expansion results;

- The dilution of alkali ions from the concrete prisms into the water results in smaller expansions than the ones obtained when prisms are soaked in saturated chemical solutions or exposed to $100 \% \mathrm{RH}$ conditions. These results confirmed that water immersion is not a good approach to develop accelerated tests; 


\section{Figure 1 - Comparative analysis: ACPST at one month $x$ CPT at one year (9)}

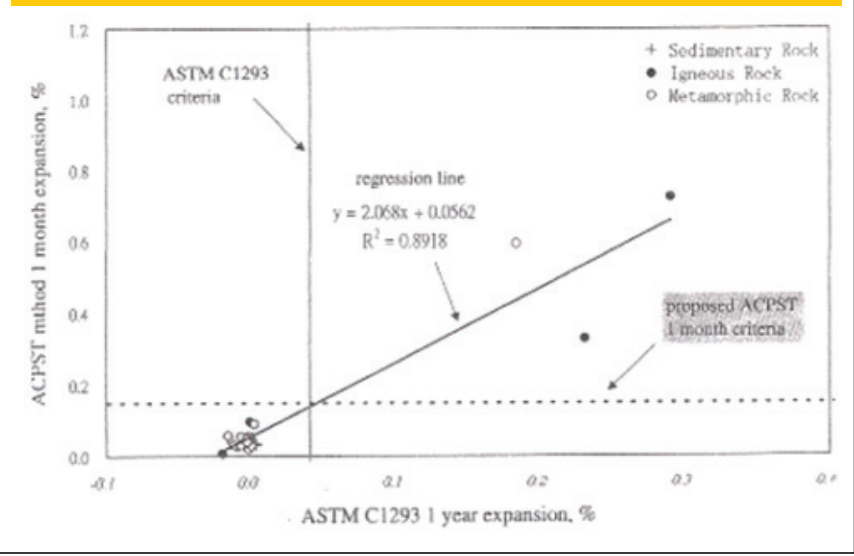

Prisms soaked in $\mathrm{NaCl}$ solutions may form chloroaluminates, which have expansive behavior and may lead to an overestimation of the expansions due to AAR at all ages. Therefore, the use of $\mathrm{NaCl}$ solutions does not seem to be a good alternative.

In 2004, Lee et al. developed an accelerated test method with prisms soaked into $\mathrm{NaOH}-1 \mathrm{~N}$ solution at $80^{\circ} \mathrm{C}$ (ACPST). The authors adopted the same concrete mix design used for CPT (ASTM C 1293) and the procedure used to measure the expansions in AMBT (ASTM C 1260). Twenty two aggregates were tested and their results were compared to CPT at 1 and 3 months. The limits chosen for both ages were $0,15 \%$ and $0,20 \%$. Figure 1 and Figure 2 show the correlations obtained.

It can be seen in the graphics that correlations with CPT at one and three months are quite good. Studying the variation of the correlation over time (Figure 3), the authors realized that, after one month, the approach to classify aggregates in the laboratory is well done. Even though this test method was considered very innovative, the authors concluded that their results were severe when comparing to the behavior of the same aggregates in the field [9].



Figure 3 - Comparative analysis: Variation of correlation $\mathrm{x}$ curing period (9)

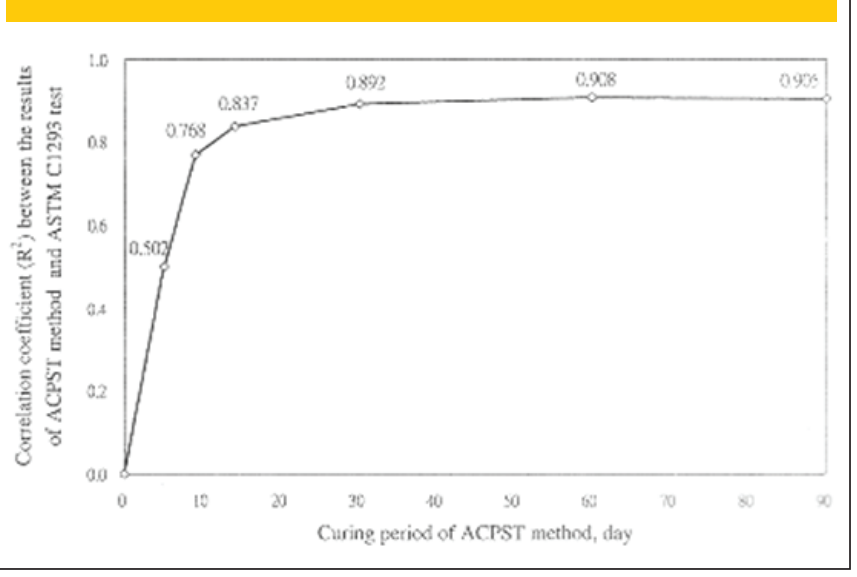

\subsection{Accelerated Brazilian concrete prism test (ABCPT)}

In view of the problems discussed above, the authors of this work developed an accelerated test method called ABCPT (accelerated Brazilian concrete prism test).

Trying to solve the problems of dilution in water, leaching in U.R. $100 \%$ and severe environment in high alkaline solutions, ABCPT is based on the concept of eliminating diffusion effects or eventually allowing only a minimum diffusion between the internal and external environments, so that the test is just accelerated by the temperature $\left(80^{\circ} \mathrm{C}\right)$. To achieve this goal, the internal alkali content $\left(\mathrm{Na}_{2} \mathrm{O}_{\mathrm{ei}}\right)$ needs to be the same as the external alkali content $\left(\mathrm{Na}_{2} \mathrm{O}_{\text {ee }}\right)$.

As the alkali content in the cement used to cast the concrete prisms needs to have $1.25 \% \mathrm{Na}_{2} \mathrm{O}_{\text {eq }}$, the alkaline solution should present the same alkali content. Considering just the influence of soluble alkali in the test (because it is an ultra-accelerated procedure), which constitute around $30 \%$ of the total alkali content, and assuming concrete porosity to be $16,5 \%$ (with a hydration degree of $90 \%$ ), the normality of the water bath should be:

$\left[\mathrm{Na}_{2} \mathrm{O}_{\mathrm{e}}\right]=\left(2 * 1,25 \% * 420 * 1000 / \mathrm{M}_{\mathrm{Na} 2 \mathrm{O}}\right) /(16,25 \%$ * 1000$)=1,041$ ${ }^{*} 0,3=0,3125 \mathrm{~N}$

In this procedure, three concrete prisms are cast according to CPT (ASTM C 1293) and they are stored in a moisture room during the first $24 \mathrm{~h}$. After that, the prisms are demolded and soaked into water during more than 24 hours. After that, the initial reading is done and concrete prisms are soaked into a $\mathrm{NaOH}$ solution with $0.3125 \mathrm{~N}$ at $80^{\circ} \mathrm{C}$ for 28 days. Readings need to be made once a week (always at the same time of the day); and the result of the test is the expansion of the prisms. Since the initial concept of ABCPT is just to accelerate the test by the temperature, and considering that the behavior of the aggregates is expected to be the same as that of CPT (at 1 year), the authors chose 1 month as the period of the test duration and $0.04 \%$ as the threshold to distinguish between reactive and innocuous aggregates.

\section{Experimental procedures}

With the aim of verifying and testing the reliability and efficiency of the new test method proposed, petrographic analysis, CPT, ACPT and $\mathrm{ABCPT}$ were carried out with the six aggregates described below. 
Table 1 - Petrographic analysis results (NBR 15577-3)

\begin{tabular}{ccc|}
\hline Aggregates & Potential reactivity & Main reactive elements \\
\hline Granite - Embu das Artes & Potentially reactive & Microcrystalline quartz \\
Basalt - Americana & Potentially reactive & Volcanic glass \\
Basalt - Birigui & Potentially reactive & Volcanic glass \\
Granite-gneiss - Recife & Potentially Reactive & Micro-cryptocrystalline quartz \\
Quartzitic gravel - Três Lagoas & Potentially reactive & Microcrystalline quartz \\
Limestone - Ottawa & Potentially Reactive & Micro-cryptocrystalline quartz \\
\hline
\end{tabular}

\subsection{Aggregates}

- Granite from Embu das Artes: the granite from Embu das Artes was chosen as the standard aggregate because is a known innocuous aggregate according to AMBT (NBR 15577-4)[10].

- Basalts from Americana and Birigui: the basalts from Americana and Birigui were chosen because according to some technical discussions, aggregates with this lithotype were used in the construction of some concrete structures affected by AAR in cities near Sao Paulo.

- Granite-gneiss from Recife: the granite-gneiss from Recife was chosen owing to its known reactive behavior in field concrete, mainly in concrete blocks from building foundations [11].

- Quartzitic gravel from Tres Lagoas: the quartzitic gravel from Tres Lagoas was chosen due to its known reactive behavior in field concrete. It was studied at IPT and CESP's laboratories for the Jupiá Dam construction [12].

- Limestone from Ottawa: the limestone from Ottawa was chosen because it is a very reactive aggregate found in Canada and it is usually used as a standard aggregate to calibrate AAR test methods in the laboratory [7].

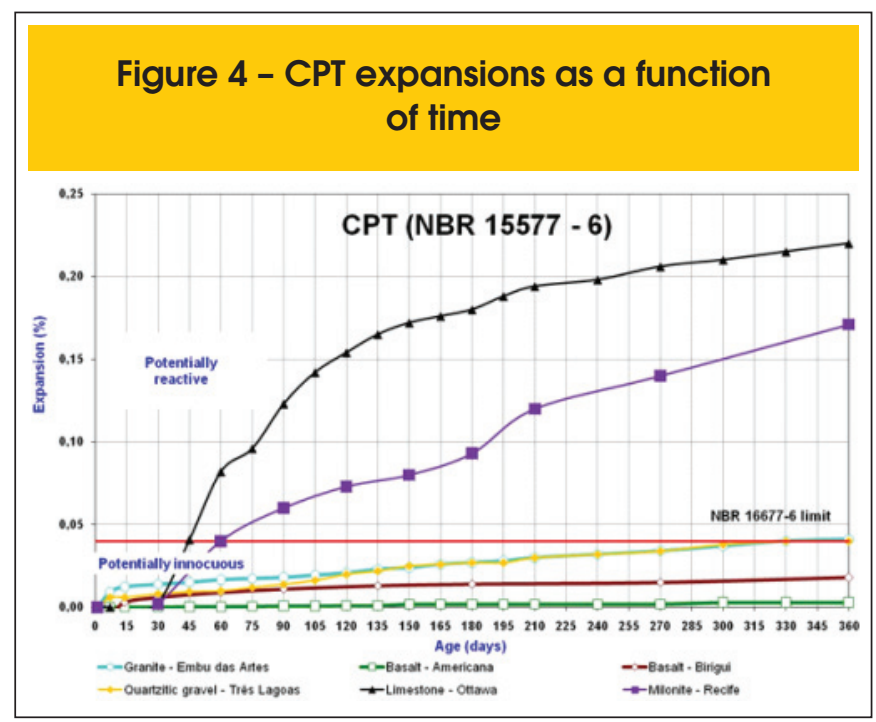

\subsection{Experiments}

The petrographic analysis was carried out according to NBR 15577-3. Meanwhile, the concrete prism test (CPT) was carried out according to NBR 15577-6 while the accelerated concrete prism test (ACPT) was carried out according to NBR $15577-6$ up to 5 months. However, the temperature used in the test was $60^{\circ} \mathrm{C}$. In the case of the Accelerated Brazilian concrete prism test (ABCPT), the specimens were cast according to NBR 15577-6. They were demolded after $24 \mathrm{~h}$ and soaked in water at $80^{\circ} \mathrm{C}$ for more $24 \mathrm{hs}$. After that, the initial readings were made and the specimens were soaked in a $0.3125 \mathrm{NaOH}$ solution up to 28 days. Readings were made once a week, always on the same time and day of the week.

\section{Results}

\subsection{Petrographic analysis}

Table 1 provides the results of the petrographic analysis. According to NBR 15577-3, all the aggregates were classified as potentially reactive.

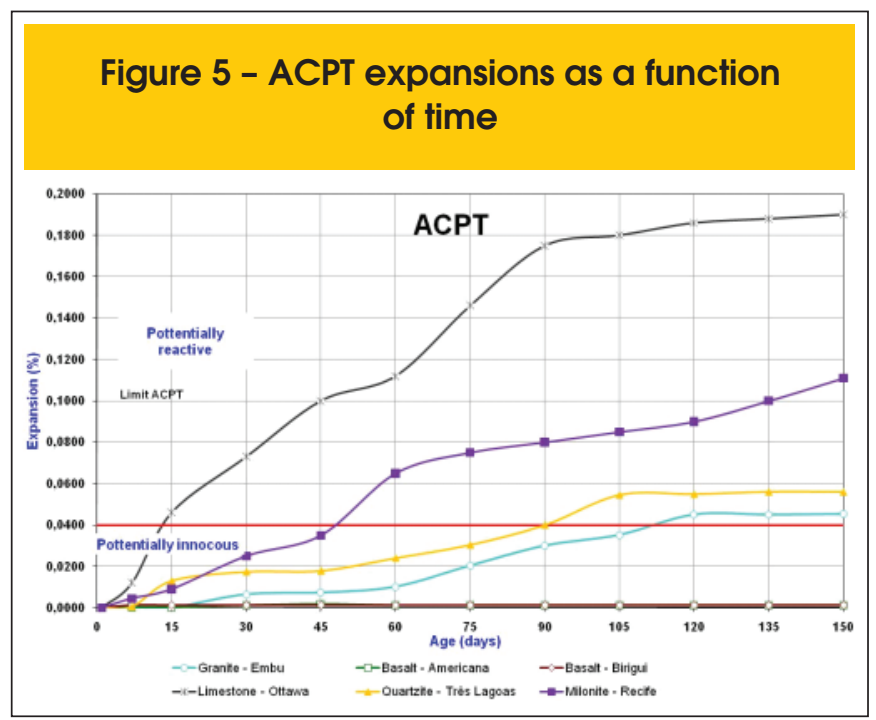




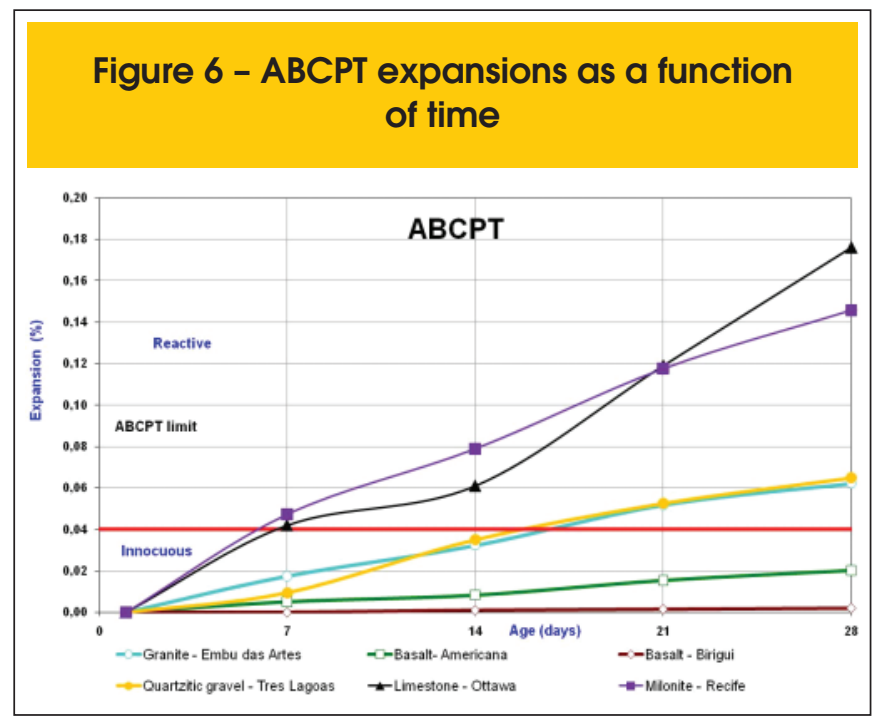

\subsection{Concrete prism test (CPT)}

Figure 4 shows the prisms expansions recorded in the CPT (NBR 15577-6) as a function of time. According to NBR 15577-6, the two basalts are potentially innocuous and the other aggregates are potentially reactive.

\subsection{Accelerated concrete prism test (ACPT)}

Figure 5 shows the prisms expansions recorded in the ACPT as a function of time. Through this test, it seems that 120 days is a better age to classify the reactivity of aggregates since those that are marginally reactive were close to the limit at 90 days.

At 120 days, the reactivity of the aggregates can be distinguished with better reliability. After this age, the rate of expansion of all the aggregates stabilized close to zero. Therefore, it seems that it is unnecessary to continue the test after 120 days, maybe because of the stabilization of expansions, caused by the leaching of the

\section{Figure 7 - Comparative analysis between CPT (NBR 15577-6) and ACPT (90 days)}

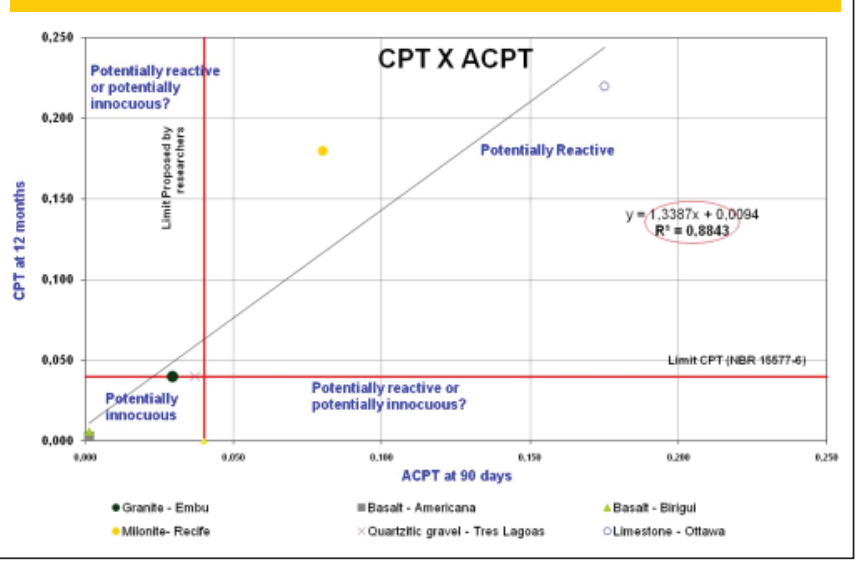

\section{Figure 8 - Comparative analysis between CPT (NBR 15577-6) and ACPT (120 days)}

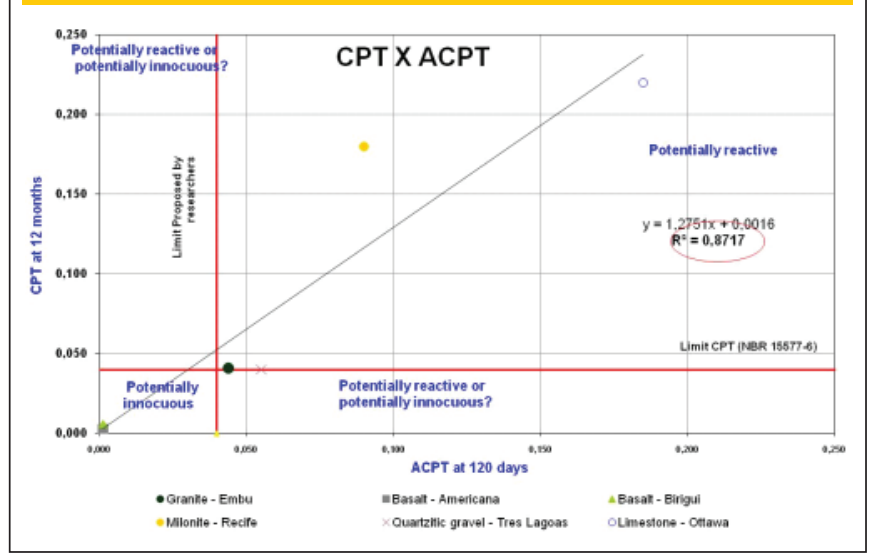

alkalis from the test prisms. Thus, the period and limit chosen to perform the comparative analysis were $0.04 \%$ at 120 days.

At 4 months, as for CPT, the basalts were classified as potentially reactive and the other aggregates as potentially innocuous.

\subsection{Accelerated Brazilian concrete prism test (ABCPT)}

Figure 6 shows the prisms expansions recorded in the ABCPT as a function of time. It can be seen that at 21 days the classification based on the ABCPT would be the same as with the CPT at one year. However, the authors agreed that carrying out the test up to 28 days is more reliable.

After just one month it was possible, like happened with the CPT and ACPT, to classify the basalts as potentially innocuous and the other aggregates as potentially reactive.

\section{Comparative analysis among test methods}

In order to compare two test methods, a graph with four quadrants was used (Fig. 7, Fig 8, Fig. 9). First and third quadrants indicate that two test methods classify the same aggregate differently. Second and fourth quadrant indicates an agreement in the classification of an aggregate by two test methods.

Figure 7 and Figure 8 compare, respectively, CPT (NBR 15577-6) and ACPT results at 90 and 120 days. In terms of correlation, there is a quite good correlation between CPT and ACPT either at 90 days or 120 days. However, it can be seen that at 90 days, 2 in 6 (33\%) aggregates were classified differently by the two test methods. On the other hand, when the aggregates are classified at 120 days, an agreement of both tests for all the samples was achieved. Figure 9 compares CPT (NBR 15577-6) at one year and ABCPT at 28 days. It can be seen that all the aggregates have the same classification by the two test methods. The coefficient of correlation can be considered quite good ( 0.89 or $89 \%)$, considering that this is an accelerated test method.

In this study it was proposed a new test method, thus it needs to be carried out with more aggregates to be confirmed as a feasible 


\section{Figure 9 - Comparative analysis between CPT (NBR 15577-6) and ABCPT (28 days)}

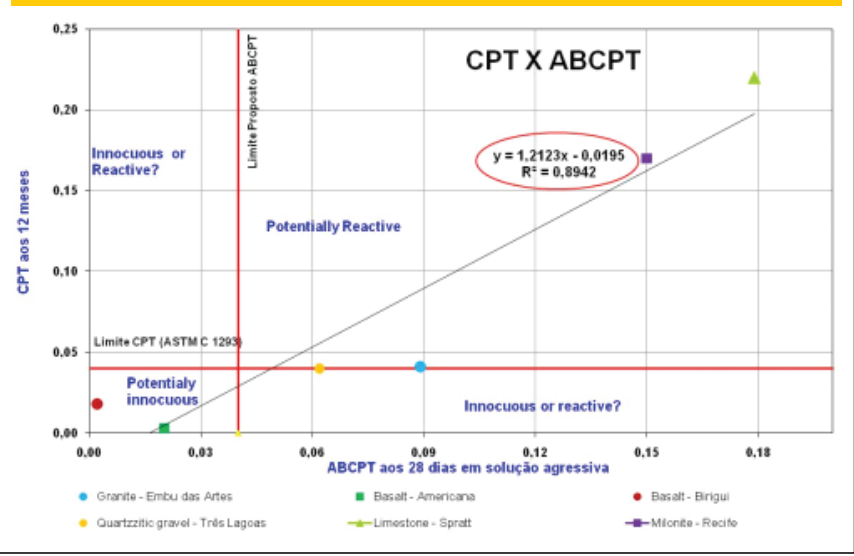

alternative for the longer test methods. Table 2 shows the global classification of all the aggregates.

\section{Conclusions}

After the analysis of the results provided by each test and by the correlations, it can be concluded that:

- Petrographic analysis is neither conclusive nor quantitative. Although all tested aggregates, in this case, were classified as potentially reactive, expansions tests suggested that two aggregates can be classified as potentially innocuous;

- In the CPT test, some slowly reactive aggregates, as the quartzitic gravel and the granite, can be at 360 days very close to the limit $(0.04 \%)$ that distinguishes potentially innocuous or potentially reactive aggregates. Care should/must be taken in the results analysis;

There is a quite good correlation between CPT and ACPT at 90 and 120 days,. However, ACPT classifies slowly reactive aggregates with less difficulty and with more agreement with CPT at 120 days. After this age, the rate of expansion for all aggregates stabilized to almost zero. It seems that the test didn't need to continue after 120 days and maybe the stabilization could be caused by the leaching of the alkalis from the prisms.

- ACPT is not standardized, however, it has a great potential to analyze reactivity of the aggregates in a fast and reliable way.

- ABCPT seems to be a good approach to analyze the potential reactivity of aggregates in the laboratory. Tests have shown that aggregates could be classified in the same way as CPT at one year as well ACPT at 4 months.

- Coefficient of correlation between ABCPT and CPT was quite good (89\%), mainly considering that $A B C P T$ is an accelerated test method.

- $\mathrm{ABCPT}$ is a new test proposed, thus it is necessary to be carried out with other aggregates to confirm as a feasible alternative for the longer test methods.

- The concretes used in the accelerated test methods (ACPT, $\mathrm{ABCPT}$, etc.) have the same characteristics (same mix-design) of the ones used in the regular test (CPT) and then one could suppose the use of different temperatures would just modify the kinetics of the chemical reaction and would not interfere in the distress mechanism due to AAR. Therefore, in most cases, the accelerated tests carried out in concrete will classify the aggregates in agreement with the standard method (unlike the methods performed in mortar, as the characteristics of the materials are not similar). However, it is very important to perform these tests with a great number of aggregates (with different lithotypes) to implement them in daily laboratory works.

\section{References}

[01] SWAMY, R. N. The alkali-silica reaction in concrete. Book. 1992, London, England.

[02] OBERHOLSTER, R.E.; DAVIES, G. An Accelerated Method for testing The Potential Alkali Reactivity of

\section{Table 2 - Global classification}

\begin{tabular}{|c|c|c|c|c|c|c|}
\hline $\begin{array}{c}\text { Test } \\
\text { Method }\end{array}$ & $\begin{array}{c}\text { Granite } \\
\text { Embu das Artes }\end{array}$ & $\begin{array}{c}\text { Basalt } \\
\text { Americana }\end{array}$ & $\begin{array}{l}\text { Basalt } \\
\text { Birigui }\end{array}$ & $\begin{array}{c}\text { Granite Gneiss } \\
\text { Recife }\end{array}$ & $\begin{array}{l}\text { Spratt } \\
\text { Ottawa }\end{array}$ & $\begin{array}{l}\text { Quartzitic } \\
\text { gravel } \\
\text { Três Lagoas }\end{array}$ \\
\hline $\begin{array}{l}\text { Petrographic } \\
\text { Analysis } \\
\text { (NBR 15577-3) }\end{array}$ & $\begin{array}{l}\text { Potentially } \\
\text { reactive }\end{array}$ & $\begin{array}{l}\text { Potentially } \\
\text { reactive }\end{array}$ & $\begin{array}{l}\text { Potentially } \\
\text { reactive }\end{array}$ & $\begin{array}{l}\text { Potentially } \\
\text { Reactive }\end{array}$ & $\begin{array}{l}\text { Potentially } \\
\text { Reactive }\end{array}$ & $\begin{array}{l}\text { Potentially } \\
\text { reactive }\end{array}$ \\
\hline $\begin{array}{c}\text { CPT } \\
\text { (NBR 15577-6) }\end{array}$ & $\begin{array}{l}\text { Potentially } \\
\text { reactive }\end{array}$ & $\begin{array}{l}\text { Potentially } \\
\text { innocuous }\end{array}$ & $\begin{array}{l}\text { Potentially } \\
\text { innocuous }\end{array}$ & $\begin{array}{l}\text { Potentially } \\
\text { reactive }\end{array}$ & $\begin{array}{l}\text { Potentially } \\
\text { reactive }\end{array}$ & $\begin{array}{l}\text { Potentially } \\
\text { reactive }\end{array}$ \\
\hline ACPT & $\begin{array}{l}\text { Potentially } \\
\text { reactive }\end{array}$ & $\begin{array}{l}\text { Potentially } \\
\text { innocuous }\end{array}$ & $\begin{array}{l}\text { Potentially } \\
\text { innocuous }\end{array}$ & $\begin{array}{l}\text { Potentially } \\
\text { reactive }\end{array}$ & $\begin{array}{l}\text { Potentially } \\
\text { reactive }\end{array}$ & $\begin{array}{l}\text { Potentially } \\
\text { reactive }\end{array}$ \\
\hline ABCPT & Reactive & Innocuous & Innocuous & Reactive & Reactive & Reactive \\
\hline Field & $?$ & $?$ & $?$ & Reactive & Reactive & Reactive \\
\hline
\end{tabular}


Siliceous Aggregates. Cement and Concrete Research, vol. 16, pp. 181-189, 1986.

[03] SANCHEZ, L.F.M., KUPERMAN, S.C., HELENE, P.R.L., KIHARA, Y. Trials to correlate the accelerated mortar bar test, the standard and the accelerated concrete prism tests. $13^{\text {th }}$ Internacional conference on alkali-aggregate reaction (ICAAR), Norway, June, 2008.

[04] THOMAS, M.; FOURNIER, B.; FOLLIARD, K.; IDEKER, J.; SHEHATA, M. Test Methods for Evaluating preventive measures for controlling expansion due the alkali-silica reaction in concrete. Paper. Cement and Concrete Research, p. 1842-1856, 2006.

[05] GRATTAN-BELLEW, G., P., E. A critical review of ultra accelerated tests for alkali-silica reactivity. Paper. Cement and Concrete Research, p. 403-414, 1997

[06] SANCHEZ, L. F. M., KUPERMAN, S. C., HELENE, $P$.R .L. ABCPT (Accelerated Brazilian concrete prism test). Brazilian Concrete Congress (IBRACONBrazilian Concrete Institute), Salvador, Brazil, September, 2008.

[07] FOURNIER, B.; NKINAMUBANZI, P.C.; LU, D.; THOMAS, M.D.A.; FOLLIARD, K.J.; IDEKER, J. Evaluating potential alkali-reactivity of concrete aggregates - How reliable are the current and new test methods? II Symposium on alkali-aggregate reaction in concrete structures. Brazilian Concrete Institute-Ibracon and Brazilian Committee on Dams-CBDB, Rio de Janeiro, Brazil, September, 2006.

[08] BERUBÉ, M.A.; FRENETTE, J. Testing Concrete for AAR in $\mathrm{NaOH}$ and $\mathrm{NaCl}$ solutions at $38^{\circ} \mathrm{C}$ and $80^{\circ} \mathrm{C}$. Cement and Concrete Composities, vol.16, pp. 189-198, 2003.

[09] LEE, C.; LIU, C.C.; WANG, C.W. An Accelerated Concrete Prism Soaking Test for Evaluating the Alkali-Reactivity of Aggregates. $12^{\text {th }}$ International Conference on Alkali-Aggregate Reaction in Concrete. Beijing, China, 2004.

[10] SANCHEZ, L. F. M. Contribution to the study of the test methods in assessing alkali-aggregate reaction in concretes. Master degree thesis, São Paulo, Brazil, May, 2008.

[11] ANDRADE, T. Historical AAR cases occurred on buildings from the metropolitan area of Recife. AAR 2006 - II Symposium on Alkali-Aggregate Reaction in Concrete Structures . Rio de Janeiro, September 2006 (Ibracon).

[12] Gitahy, H. S. O problema dos agregados para os concretos da barragem de Jupiá. IPT - Instituto de Pesquisas Tecnológicas do Estado de Sao Paulo, Março, 1963. 